\title{
Relative impact of recent climate and land cover changes in the Godavari river basin, India
}

\author{
Narendra Hengade and T I Eldho* \\ Department of Civil Engineering, Indian Institute of Technology Bombay, Mumbai 400 076, India. \\ *Corresponding author. e-mail: eldho@civil.iitb.ac.in
}

MS received 24 July 2018; revised 27 October 2018; accepted 21 November 2018; published online 2 April 2019

The Godavari river basin (GRB), the second largest river basin $\left(312,800 \mathrm{~km}^{2}\right)$ in India, was considered in this study to quantify the relative hydrological impact of recent land cover (LC) changes and rainfall trends using the variable infiltration capacity hydrologic model. Three scenarios, namely, (i) LC change, (ii) climate change and (iii) LC and climate changes, were considered to isolate the hydrological implications of the LC changes from those of climate change. Results revealed that evapotranspiration is predominantly governed by LC change and that small changes in rainfall cause greater changes in the runoff. Although the spatial extent of LC change is higher, the climate change is the dominant driver of hydrological changes within the GRB. Thus, climate projections are the key inputs to study the impact on the river basin hydrology. The results provide insights into the impacts of the climate and LC changes on the basin. The methodology and results of the present study can be further considered for water resource planning within the river basin in view of the changing environment.

Keywords. LC change; climate change; Godavari river basin; macroscale hydrological model.

\section{Introduction}

The significant impact of land cover (LC) changes and climate change on hydrologic cycle and water resources has been investigated in recent years. Both the LC changes and climate change have intensified several water resource-related problems, such as water scarcity, floods and water balance within the river basin. Hydrological models are extensively used to evaluate the impact of land use changes and climate change on water resources and hydrology of river basin (Hamlet and Lettenmaier 1999; Bewket and Sterk 2005; Morán-Tejeda et al. 2010; Cuo et al. 2013; Huo and Li 2013; Liu et al. 2013; Guo et al. 2016; Yan et al. 2016). Many macroscale hydrological models (MHMs), which can be used to simulate the land surface hydrologic processes at the river basin scale, have been developed over the recent years (Nijssen et al. 2001; Maurer et al. 2002). As the microscale hydrological process may not be able to govern large-scale watersheds because of scale dependence (Dunn 1998), MHMs were developed to study the hydrological response/change at the river basin scale. MHMs are powerful tools for studying the spatial variability in hydrologic variables and the impact of LC changes and climate change at the basin scale. The variable infiltration

Supplementary material pertaining to this article is available on the Journal of Earth System Science website (http://www. ias.ac.in/Journals/Journal_of_Earth_System_Science). 
capacity (VIC) model (Liang et al. 1994, 1996) is an example of MHMs.

Changes in LC have caused a considerable shift on the Earth's surface from forests to croplands and from croplands to urban areas (Foley et al. 2005). Several studies have been performed to show the impact of LC and climate changes on water resources (Savary et al. 2009; Jiang et al. 2015) and flood intensification (Saghafian et al. 2008). Kristensen and Jensen (1975), Dooge et al. (1999), and Koster and Suarez (1999) proposed approaches to estimate runoff changes due to precipitation and potential evaporation. Babar and Ramesh (2015) proposed a runoff coefficient routing model for the Netravathi river basin, India, and estimated a decrease in evapotranspiration, an increase in the runoff and an increase in groundwater caused by LC change. Dong et al. (2015) reported that the impact of LC change is higher than that of climate change on the direct runoff in the Wei river basin, China. Therefore, it is essential to isolate the impact of climate change from that of LC changes on the hydrological processes in the concerned study area.

The trend analysis of meteorological variables such as rainfall and temperature is important to identify the long-term statistical changes in data series (Burns 2008), which provides additional information regarding data behaviour that normally reflects the change in the hydrological cycle. Using a hydrological model in combination with an appropriate statistical model is a useful approach to examine the long-term hydrological changes.

The VIC model has been employed on a global scale (Nijssen et al. 2000, 2001) as well as the continental scale (Maurer et al. 2002). Raje and Krishnan (2012) demonstrated the feasibility and relevance of a Bayesian approach to model parameter uncertainty of the VIC model using streamflow for Ganga, Narmada and Krishna rivers. The study found that the uncertainty due to the selection of GCM is larger than the parameter uncertainty. Aggarwal et al. (2013) evaluated the ability of the VIC model to simulate the water balance of entire India. The study indicates that the VIC model considers a large number of parameters governing the hydrological process. It is also found that the VIC model can be employed to obtain the water balance at a different scale. Shah and Mishra (2016) examined the long-term changes (19012012) in hydro-climatic variables for 18 Indian basins using the VIC model. The study showed that changes in large-scale climate variables may affect future water availability in Indian basins. Recently, Hengade and Eldho (2016) assessed the suitability of VIC hydrologic model for a mediumsize Ashti catchment in Maharashtra, India, and showed its effectiveness. The suitability of the VIC hydrologic model in the Indian monsoon conditions and especially larger river basin scale has not been widely explored yet. In the current study, the VIC hydrologic model was employed to obtain the water fluxes within the Godavari river basin (GRB). Streamflows were gauged with high precision compared to other fluxes and are an effective indicators of the hydrological changes at the basin scale. The observed streamflows were used to compare the simulated streamflow to understand the model's capabilities and efficiency. The aims of the present study are three fold: (i) to estimate the isolated impact of LC changes on the Godavari basin hydrology, (ii) to assess the isolated impact of climate change on the Godavari basin hydrology and (iii) to evaluate the combined impact of climate change and LC changes on the GRB.

\section{Study area and data}

The GRB is situated between latitudes $16^{\circ} 07^{\prime}-22^{\circ} 50^{\prime} \mathrm{N}$ and longitudes $73^{\circ} 21-83^{\circ} 09^{\prime} \mathrm{E}$ in the Deccan plateau of India. The basin area of the Godavari river measures up to $312,800 \mathrm{~km}^{2}$, which is nearly one-tenth of the area of India. The basin covers areas in the states of Maharashtra (48.5\%), Andhra Pradesh (23.3\%), Chhattisgarh (12.5\%), Madhya Pradesh (8.6\%), Orissa (5.7\%) and Karnataka (1.4\%). The Godavari is the second largest river basin in India, surrounded by Satmala hills, Ajanta range, Mahadeo hills, the Eastern Ghats and the Western Ghats. The source of the Godavari river is at an altitude of $1067 \mathrm{~m}$ at the Sahyadri hills near Triambakeshwar in Nashik district of Maharashtra. After traversing a distance of approximately $1465 \mathrm{~km}$, the river joins the Bay of Bengal. The average yearly rainfall in the Godavari basin is $1100 \mathrm{~mm}$ with large spatial and temporal variation. The location of the GRB is shown in figure 1(a).

The soil information data extracted from the digitised global soil map derived by the Food and Agriculture Organization of United Nations (FAO 2003 ) is presented in figure 1(b), indicating the predominance of clay and sandy clay loam that account for low infiltration rate and higher runoff in the basin. Grid-wise soil parameters were obtained 


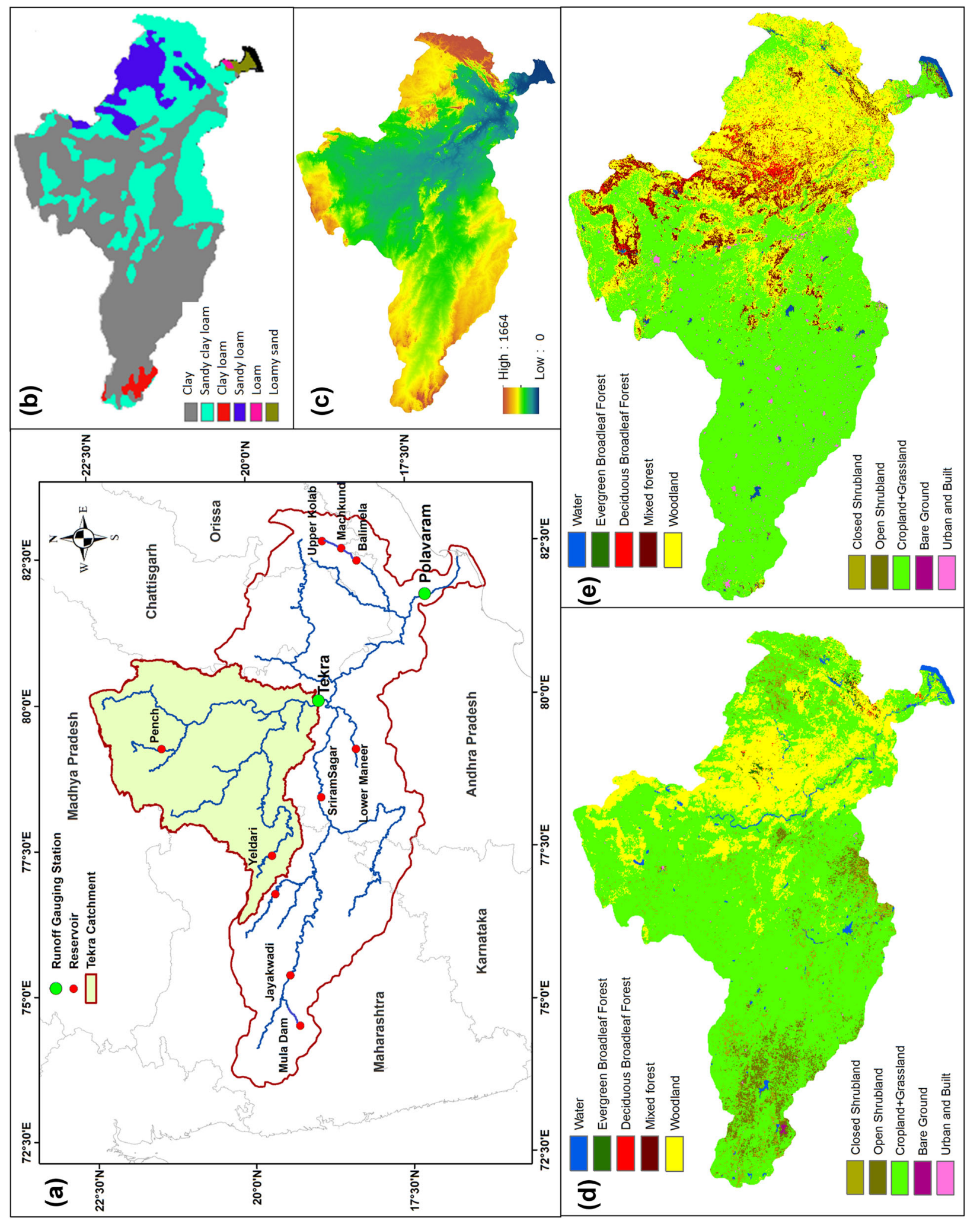

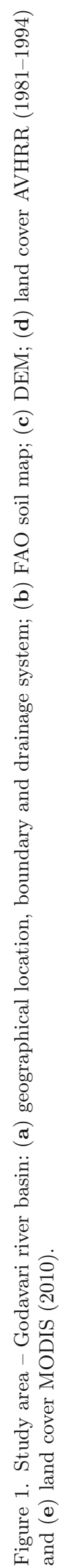


for both soil layers at $300 \mathrm{~mm}$ (layer 1) and $700 \mathrm{~mm}$ (layer 2) to initiate the model. The digital elevation model (DEM) generated from the Shuttle Radar Topography Mission dataset with a spatial resolution of $90 \mathrm{~m}$ was employed to delineate the GRB boundary as shown in figure $1(\mathrm{c})$. Figure $1(\mathrm{~d})$ presents a global LC for the GRB with a 1-km spatial resolution, as derived from the advanced very high resolution radiometer (AVHRR) data produced by the University of Maryland. The time period of development of AVHRR LC (19811994) is consistent with the model calibration period (1981-1995). Hence, AVHRR LC data was employed for calibration and validation of the VIC model and establishing the base line to show LC changes. Figure 1(e) presents the MODIS LC map (2010) for the GRB at $500 \mathrm{~m}$ spatial resolution. MODIS LC dataset was employed to run the calibrated and validated VIC model, and to simulate the impact of LC change on the hydrologic variables with respect to the base line LC map. The LC changes and its impact on the GRB hydrology are discussed in section 4.2 .

The gridded daily rainfall data at $0.25^{\circ} \times 0.25^{\circ}$ resolution and gridded daily maximum and minimum temperatures at $1^{\circ} \times 1^{\circ}$ resolution by the Indian Meteorological Department (Rajeevan et al. 2005) were collected from 1981 to 2010. The National Center for Environment Predictions $(\mathrm{NCEP} / \mathrm{NCAR})$ reanalysis data at $2.5^{\circ} \times 2.5^{\circ}$ resolution (Kalnay et al. 1996) were used to obtain wind speed. Daily observed streamflows for the period of $30 \mathrm{yr}$ (1981-2010) were acquired from the Central Water Commission (CWC, Ministry of Water Resources, India) to calibrate and validate the VIC model. The description input data for the present study is also tabulated in supplementary table S1.

\section{Model and methodology}

\subsection{The VIC hydrologic model}

The VIC hydrologic model is a macroscale hydrologic model, which can solve the water balance or water-energy balance equation at each grid cell independently and can be used for three soil layers (Liang et al. 1994, 1996). The following equation shows the water balance in the VIC model:

$$
\frac{\partial S}{\partial t}=P-E-R
$$

where $\partial S / \partial t$ is the change in storage per day, $P$ is the precipitation per day, $E$ is the evapotranspiration per day and $R$ is the runoff per day. The VIC model is a spatially distributed hydrologic model formulated for large river basins with reasonably coarse uniform grids so that it can accept the meteorological variables input directly from the global gridded datasets or general circulation models (GCMs.). To compensate for the coarse spatial resolution during discretisation, the sub-grid variability was incorporated to describe heterogeneity in the LC parameters.

The land surface is represented horizontally by different vegetation classes using fractional coverage areas and their characteristics. The VIC model focuses on evapotranspiration, which is sensitive to land use change. The evapotranspiration for each vegetation class is calculated using the Penman-Monteith equation. The actual total evapotranspiration at each grid cell includes canopy evaporation, transpiration and bare soil evaporation, weighted by the coverage area fraction for each vegetation class.

The VIC two-layer (VIC-2L) model (Liang et al. 1994) includes upper and lower soil layers. The upper soil layer represents the dynamic behaviour of the soil to rainfall events. The bottom soil layer represents the seasonal soil moisture behaviour. Based on soil moisture conditions of the lower soil layer and flow rates, the baseflow changes both linearly and nonlinearly. The one-dimensional Richards equation governs the vertical moisture movement between different layers of soil. The VIC model adopts the conceptual ARNO baseflow formulation (Todini 1996) to obtain the subsurface runoff from the bottom layer. The VIC model employs the variable infiltration curve to account for the spatial heterogeneity of runoff generation.

The fluxes derived from the VIC model were transferred to the stand-alone routing model (Lohmann et al. 1996). The routing model routes the VIC model-derived water fluxes such as surface runoff and baseflow to the grid cell outlet and then into the river drainage system to compute the flow hydrograph at a particular runoff gauging location.

\subsection{Setting the VIC hydrologic model for the Godavari river basin}

In the present study, the VIC-2L model was used to evaluate the hydrologic responses to the $\mathrm{LC}$ and climate changes in the GRB. Figure 2 presents the flow chart for the VIC model calibration. The 


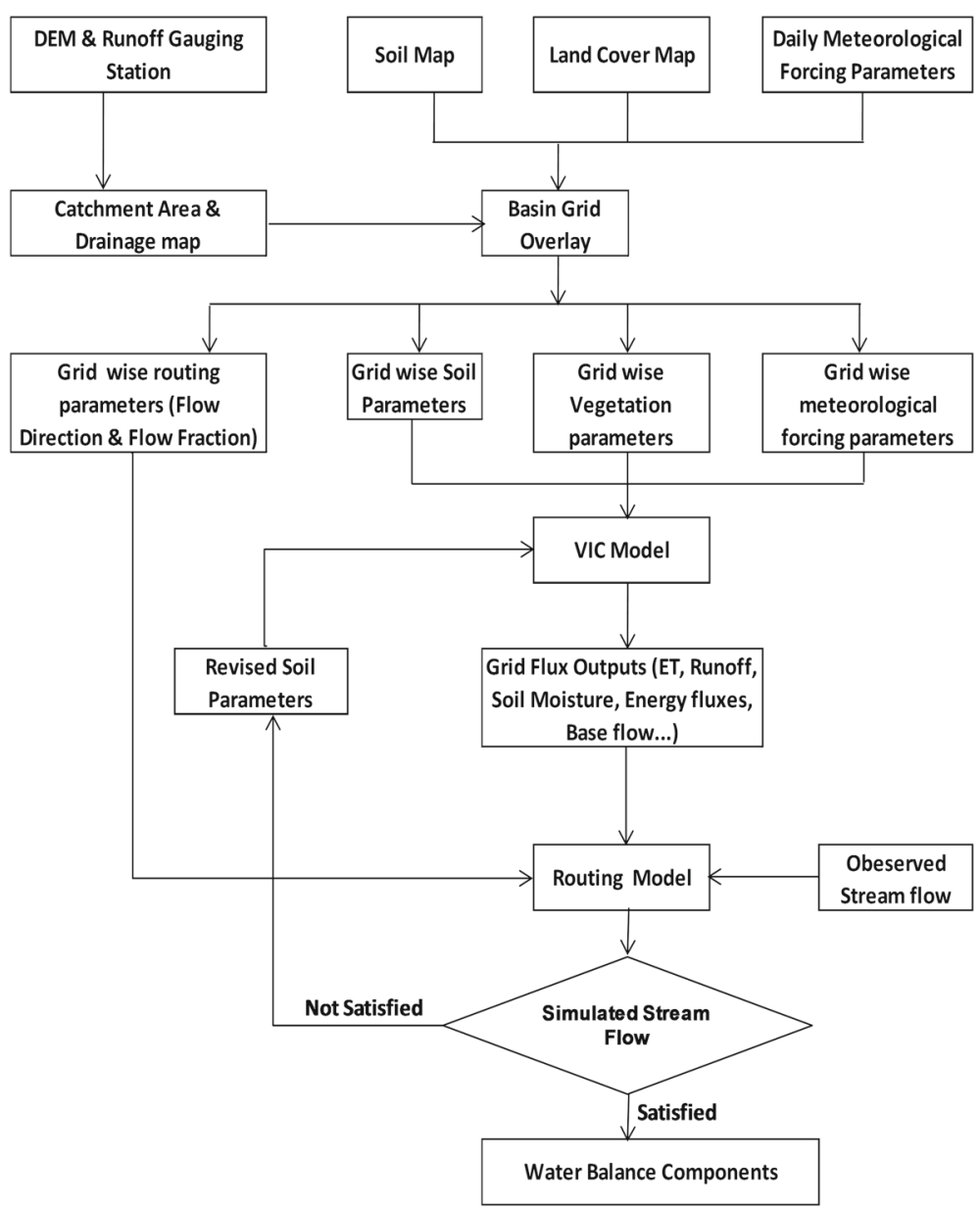

Figure 2. Flow chart for the VIC model calibration.

GRB is partitioned into 580 uniform grid cells of $25 \times 25 \mathrm{~km}$ to cover the study area (supplementary figure S1a). The generated grids were overlaid with other thematic layers of DEM, LC map and soil map to extract various parameters at individual grid (topographic parameters, soil properties and vegetation classes). The grid-wise daily meteorological variables (precipitation, maximum and minimum temperatures, and wind speed) were extracted and the grid-wise distribution of various parameters within the river basin was defined. The grid-wise fluxes computed using the VIC model contain mainly runoff, evapotranspiration, baseflow and soil moisture. The water fluxes derived using the VIC hydrologic model along with flow direction (supplementary figure S1b) and flow fraction (supplementary figure S1c) were transferred to flow routing model (Lohmann et al. 1996) to compute the flow hydrograph at a specified outflow location. The routing model simulated flow hydrographs can be compared with the observed flow hydrographs at the gauging stations to understand the model performance.
The VIC model was calibrated (1981-1995) and validated (1996-2010) at the Tekra runoff gauging station as there is no major storage structure/reservoir except the small sub-catchment of the Pench reservoir within the Tekra catchment. The Pench reservoir with a catchment area of $4660 \mathrm{~km}^{2}$ is very small compared with the total catchment area of Tekra $\left(108,780 \mathrm{~km}^{2}\right)$. The total annual runoff generated at the Pench reservoir is $2257.84 \mathrm{MCM}$ and its storage capacity is 180 MCM, i.e., $7.97 \%$ of the total runoff generated. Therefore, the impact of the storage structure on the observed streamflows is assumed to be minimal, and simulations were conducted without considering the impact of the storage structure in the absence of storage and release data of the Pench reservoir.

Remote sensing data and geographical information systems (GIS) techniques are the most efficient methods to retrieve, process and distribute the physical parameters over a larger river basin. The VIC model considers a large number of land surface variables influencing the hydrology. In the 
present study, the available remote sensing global dataset (DEM and LULC) and soil data were processed to build a grid-wise dataset for the GRB using GIS techniques.

\subsection{Detrended meteorological data}

The linear regression model was proposed to fit the meteorological dataset. The grid-wise detrended meteorological data, i.e., daily rainfall, daily temperature (maximum and minimum), and daily wind speed were obtained by eliminating the significant trends (increasing/decreasing) in the observed data series from 1981 to 2010. The detrended and observed meteorological data were used to evaluate the changes in hydrological response caused by climate change. Following steps were adopted to generate the grid-wise detrended rainfall data series:

1. The grid-wise daily rainfall data series at each grid for the period of $30 \mathrm{yr}$ (1981-2010) was considered for the trend analysis.

2. The daily rainfall data series were separated for different seasons, i.e., December-JanuaryFebruary (DJF), March-April-May (MAM), June-July-August-September (JJAS) and October-November (ON). Thus, the daily rainfall data for $30 \mathrm{yr}$ were divided into four data series for four seasons at each grid.

3. The grid-wise seasonal sum of rainfall data for 30 yr (30 data points for each season) was generated. Therefore, the grid-wise seasonal data series of rainfall were developed for further analysis separately using

$$
\begin{aligned}
& \text { Seasonal sum of rainfall } \\
& =\sum_{i=1}^{N \text {-days }}(\text { Daily rainfall data })
\end{aligned}
$$

where $i$ is the first day and the total number of days within the season are represented by $N$-days.

4. The grid-wise time series of the observed seasonal sum of the rainfall was adopted for the trend analysis. The statistically significant increasing or decreasing linear trend for each grid was obtained using linear regression:

$$
\text { Seasonal sum of rainfall }=m t+C \text {, }
$$

where $t$ is the independent time variable, seasonal rainfall sum is the dependent variable, $m$ is the slope of the line and $C$ is the intercept. The probability values ( $p$-value) criterion was adopted to identify the significant increasing or decreasing trends within the particular rainfall data series. The $p$-value is obtained against the null hypothesis $\mathrm{H}_{0}$ (no trend). If the $p$-value is less than the significance level $(\alpha)$ of 0.05 , then the hypothesis is rejected. Rejecting the null hypothesis implies that the trend is statistically significant at the significance level $(\alpha)$ of 0.05 , whereas accepting $\mathrm{H}_{0}$ implies no trend in the observed data.

5. The seasonal detrended rainfall data series was computed using equation (4) only for the grids that show a statistically significant trend:

$$
\begin{aligned}
& (\text { Detrend seasonal sum })_{i=1}^{j=30} \\
& \quad=(\text { observed seasonal sum })_{i=1}^{j=30}-m .
\end{aligned}
$$

6. The detrended daily rainfall data series for the respective season was computed as shown in

$$
\begin{aligned}
\text { Detrend daily rainfall }= & \text { observed daily rainfall } \\
& \times \frac{\text { detrend season sum }}{\text { observed seasonal sum }} .
\end{aligned}
$$

The grid-wise rainfall trends were analysed using the seasonal sum of rainfall while for the other meteorological variables of maximum temperature, minimum temperature and wind speed, the analysis was performed using the seasonal average as these are instantaneous variables. Thus, a series of detrended meteorological data for an equal time period as that of the observed data were obtained. The meteorological data after removing the trends were used in the VIC hydrologic model for simulating the impact of climate change on the hydrologic variables, and the results are discussed in section 4.3.

\subsection{Simulation scenarios}

The impact of LC and climate changes on the hydrological variables was quantified separately for the GRB. The change in hydrological variables was estimated using the VIC hydrologic model by considering the following three different scenarios:

(i) LC change: The change in the hydrological variables due to the LC changes was evaluated. Two LC datasets, i.e., 'AVHRR LC (1981-1994) and MODIS LC (2010)', were employed to obtain the LC changes. It is believed that the MODIS data are more accurate than the AVHRR data (Cao et al. 2008). 
However, the AVHRR data are available for the period of $1980 \mathrm{~s}$, whereas the MODIS data are available since 2001. Moreover, the global AVHRR 1-km LC data establish the baseline to show the change in LC with respect to newer sensors such as MODIS (Hansen et al. 2000). Evaluation of the consistency of the AVHRR and MODIS is beyond the scope of the present study. However, investigation of the consistency of the MODIS and AVHRR may provide more insight into land change cover before employing it for climate studies. The AVHRR 1-km data have been developed using the vegetation classes by the University of Maryland and MODIS uses the International Geosphere-Biosphere Programme (IGBP) vegetation classes classification. Hansen et al. (2000) provide the UMD vegetation classes, i.e., AVHRR and corresponding IGBP-DIS (MODIS) vegetation classes. Most of the vegetation classes are common in both the datasets with three additional vegetation classes in MODIS data, i.e., Permanent Wetlands, Natural Vegetation Mosaics, and Snow and Ice. These three additional vegetation classes are not the observed within the GRB.

The impact of climate change was nullified by removing the trends in the meteorological data over the simulation period (1981-2010) to isolate the implication of LC changes.

(ii) Climate change: The change in the hydrological variables due to the change in the rainfall trends was evaluated over the period of $30 \mathrm{yr}$ (1981-2010). The two meteorological datasets, i.e., 'observed and detrended data', were employed to obtain the climate change. The detrended meteorological data were obtained according to the methodology explained in section 3.3. The LC was assumed to be constant over the simulation period (1981-2010) to isolate the implication of climate change.

(iii) Climate change and $L C$ change: The changes in the hydrological variables were simulated by considering the combined impact of the LC changes and climate change scenarios. The hydrological variables were simulated for two runs using: (i) detrended meteorological data and AVHRR LC data (1981-1994) termed as 'baseline run' and; (ii) observed meteorological data and recent MODIS LC data (2010) named as 'climate and LC-induced run.' The change in the hydrological variables caused by the differences between 'climate and LCinduced run' and 'baseline run' represented the combined implication of LC changes and climate change over a period of $30 \mathrm{yr}$.

The calibrated soil parameters were maintained constant for all the scenarios.

\section{Results and discussion}

The current study attempted to investigate the implications of LC changes and climate change on the basin hydrology using the VIC hydrologic model. The observed and simulated streamflows are equated with the simulated streamflows to calibrate and validate the VIC model at the Tekra station. Both the catchments, Tekra and Polavaram, are almost identical in terms of LC and soil type. The Polavaram catchment covers the grassland/cropland area of $70.22 \%$ and woodland area of $20.18 \%$, whereas the Tekra catchment covers the grassland/cropland area of $79.51 \%$ and woodland area of $17.67 \%$ as shown in supplementary table S2. Both the catchments cover more than $90 \%$ clay and sandy clay loam as shown in supplementary table S3. Therefore, in a general way, the calibrated soil properties for Tekra can be transferred to the Polavaram station as the standard soil properties remain the same irrespective of catchment size. Hence, to simulate the streamflows along with other hydrological variables in the GRB, the calibrated parameters were transferred at the Polavaram station $\left(307,800 \mathrm{~km}^{2}\right)$. The impact of LC and climate changes on the GRB was evaluated.

\subsection{Model calibration and validation}

The observed runoff was compared with the model-simulated runoff to understand the model capabilities. The grid-wise fluxes for the GRB were obtained using the VIC hydrologic model. Mainly, four dominant soil parameters, (i) variable infiltration curve parameter $\left(b_{\text {inf }}\right)$, (ii) maximum velocity of baseflow from the bottom soil layer $\left(D_{\mathrm{m}}\right)$, (iii) fraction of $D_{\mathrm{m}}\left(D_{\mathrm{s}}\right)$ and (iv) fraction of maximum soil moisture $\left(W_{\mathrm{s}}\right)$, were accounted to calibrate as they cannot be derived from the standard soil properties. The adopted range of these parameters is shown in table 1 . The VIC model-derived water fluxes were obtained at each grid cell. To compute the simulated streamflows at specified outlet 
Table 1. Dominant soil parameters for calibration in the VIC hydrologic model.

\begin{tabular}{llcc}
\hline Calibration parameter & \multicolumn{1}{c}{ Description } & Accepted range & Adopted values \\
\hline$b_{\text {infilt }}$ & Variable infiltration curve parameter & $10^{-5}-0.4$ & 0.2 \\
$D_{\text {smax }}$ & Maximum velocity of baseflow (mm/day) & $0-30$ & 15 \\
$D_{\mathrm{s}}$ & $\begin{array}{c}\text { Fraction of } D_{\text {smax }} \text { where nonlinear } \\
\text { baseflow begins }\end{array}$ & $0-1.0$ & 0.01 \\
$W_{\mathrm{s}}$ & Fraction of maximum soil moisture where & $0-1.0$ & 0.8 \\
& nonlinear baseflow occurs & & \\
\hline
\end{tabular}

location of the river basin, the VIC model simulated water fluxes at each grid cell were routed using the stand-alone routing model (Lohmann et al. 1996).

Daily simulations were performed and the monthly simulated streamflows were equated with the observed monthly streamflows to assess the model accuracy at Tekra (figure 3) and Polavaram (figure 4) runoff gauging stations. It is observed that the simulated streamflows are in good agreement with the observed streamflows at both the locations. Figure 5 represents the spatial variation in water fluxes such as evapotranspiration, surface runoff and baseflow over the GRB. The spatial pattern of the observed rainfall was very well captured by the VIC simulated runoff. The average annual runoff simulated by the VIC model was $100.97 \mathrm{BCM} / \mathrm{yr}(322.80 \mathrm{~mm} / \mathrm{yr})$, which is in reasonable agreement with the observed runoff value of $90.13 \mathrm{BCM} / \mathrm{yr}$ and simulated runoff value of 95.45 BCM/yr by National Remote Sensing Centre and Central Water Commission (2011).

The performance criteria adopted in the present study for the model calibration and validation are the coefficient of efficiency (Nash and Sutcliffe coefficient $\left.-N_{\mathrm{s}}\right)$, the coefficient of determination $\left(R^{2}\right)$ and the relative error (RE). At the Tekra runoff gauging station, the model performance indicators were obtained. The $N_{\mathrm{s}}$ value was 0.94 at monthly scale and 0.42 at a daily scale, RE was less than $1.62 \%$ at monthly scale and $1.23 \%$ at a daily scale, and $R^{2}$ was 0.91 at monthly scale and 0.37 at daily scale for the calibration during 1981-1995. For the validation period during $1996-2010$, the $N_{\mathrm{s}}$ value was 0.79 at monthly scale and 0.27 at a daily scale, RE was less than $16.79 \%$ at monthly scale and $15.86 \%$ at a daily scale, and $R^{2}$ was 0.75 at monthly scale and 0.32 at daily scale. The performance indicators are better at monthly scale than that of daily scale due to several reasons. Firstly, monthly values eliminate the difference in the high or low discharges at daily scale and consider average values for a respective month. Secondly, it is observed that even 1-day shift in the observed and simulated hydrograph at daily scale and at a specific runoff gauging station is possible due to the model capabilities and scale of the river basin (figures S2 and S3). Thirdly, operations of storage structure may cause higher errors in the performance indicator at daily scale than that of monthly/seasonal scale. The objective of the present study was to evaluate water balance components at seasonal scale especially for monsoon season (JJAS). Hence, the results presented at a monthly scale are reasonable to evaluate the model performance. It is found that the model performance was decreased from 1996 to 2010 (validation period) due to significant overestimation of the simulated streamflows was observed for a few specific years (figure 3 ). The set of calibrated parameters at the Tekra runoff gauging station was used for the Polavaram runoff gauging station to minimise the impact of the storage structure on the calibrated parameters. The impact of the storage reservoirs on the discharges at the Polavaram station was higher than that at the Tekra station. At the Polavaram station, the $\mathrm{N}_{\mathrm{s}}$ value obtained was $0.75, R^{2}$ was 0.86 , and the relative error between the observed and simulated annual generated runoff (mm) was $15.03 \%$ during 1981-2010. The performance of the model decreases as the catchment area increases. The deficiencies in model calibration are cumulative with the increasing area, and the hydrological processes within the catchment may not be dominant at large watersheds due to the difference in the spatial scale (Dunn 1998). Furthermore, the VIC simulates the naturalised flow without considering reservoirs, dams and any other storage structures.

\subsection{LC changes}

The LC changes for two different periods, i.e., AVHRR LC (1981-1994) and MODIS LC (2010) were determined and their impact on the hydrological processes was evaluated. Detailed information on the land use change is summarised in table 2 for 

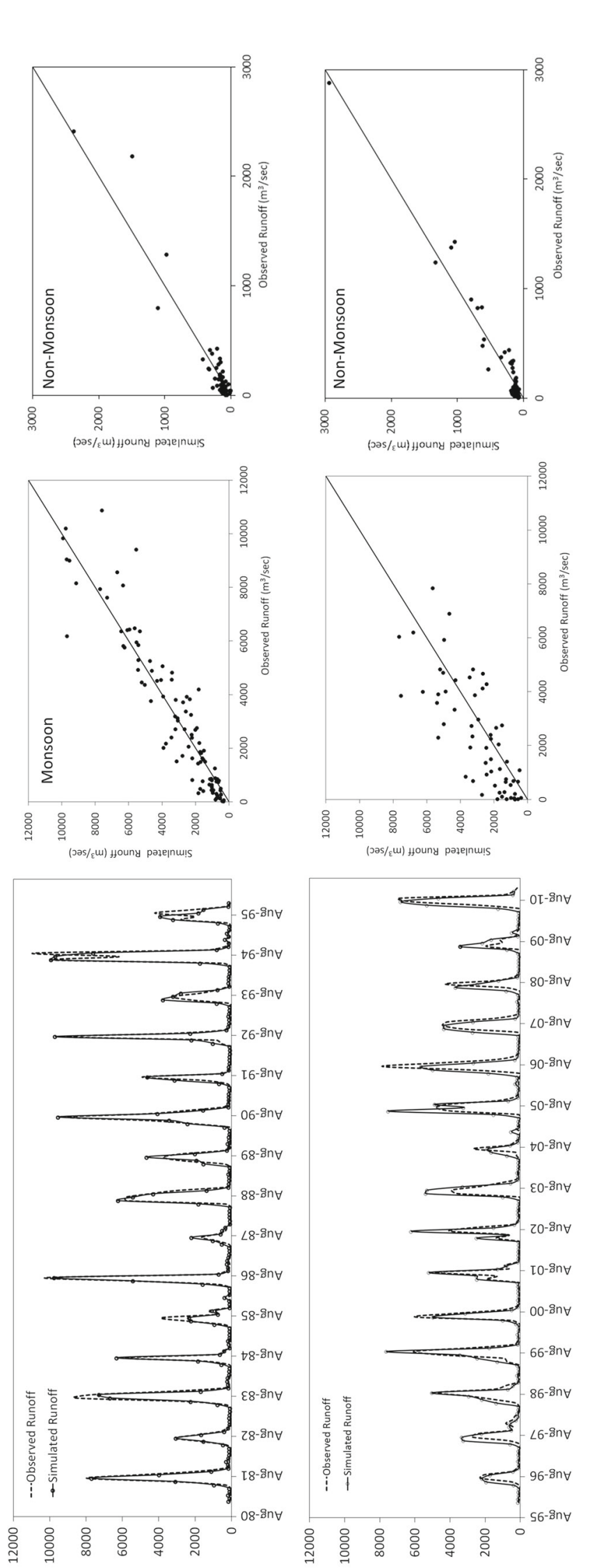

(כəs/عس) Houny

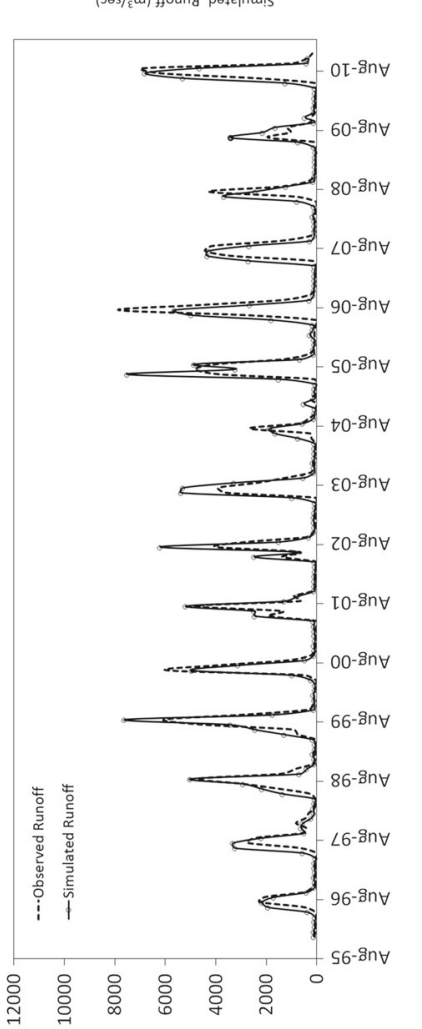

(Jəs/عس) Houny 


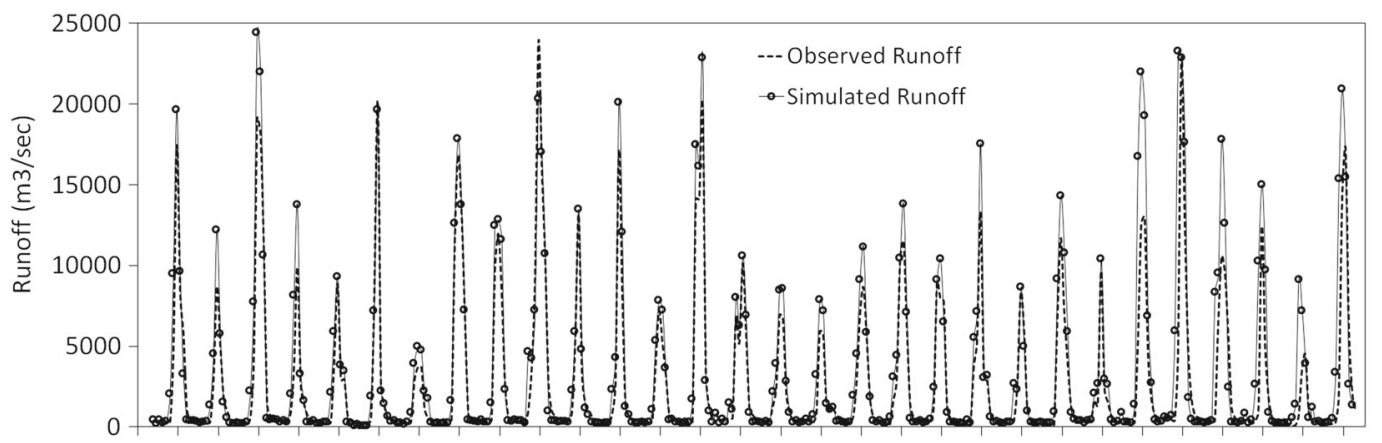

○

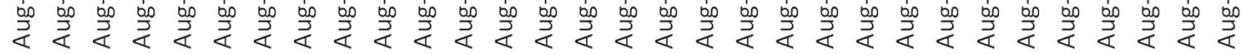
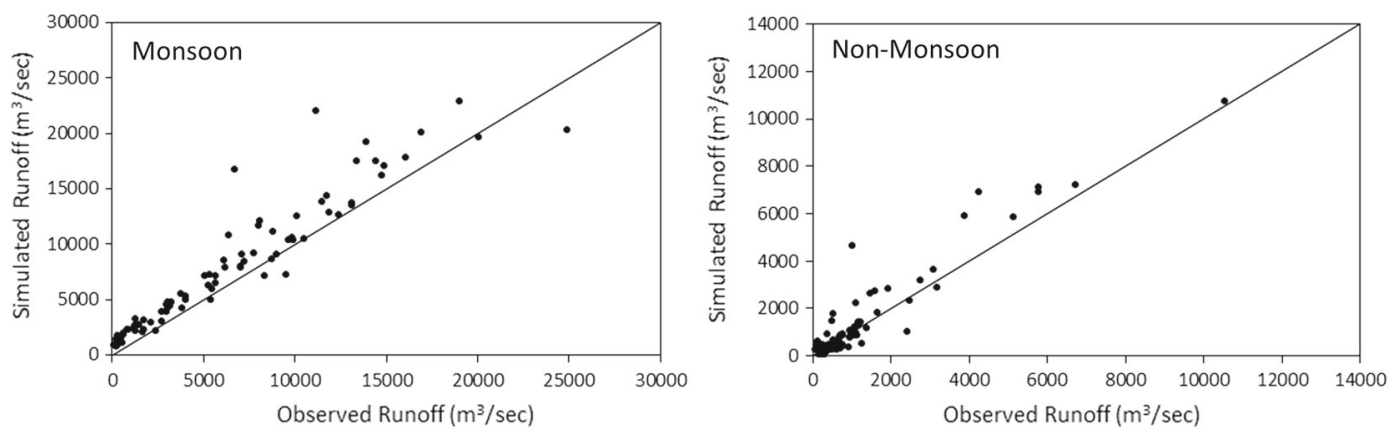

Figure 4. Comparison between the observed and simulated streamflows during 1981-2010 at Polavaram station.
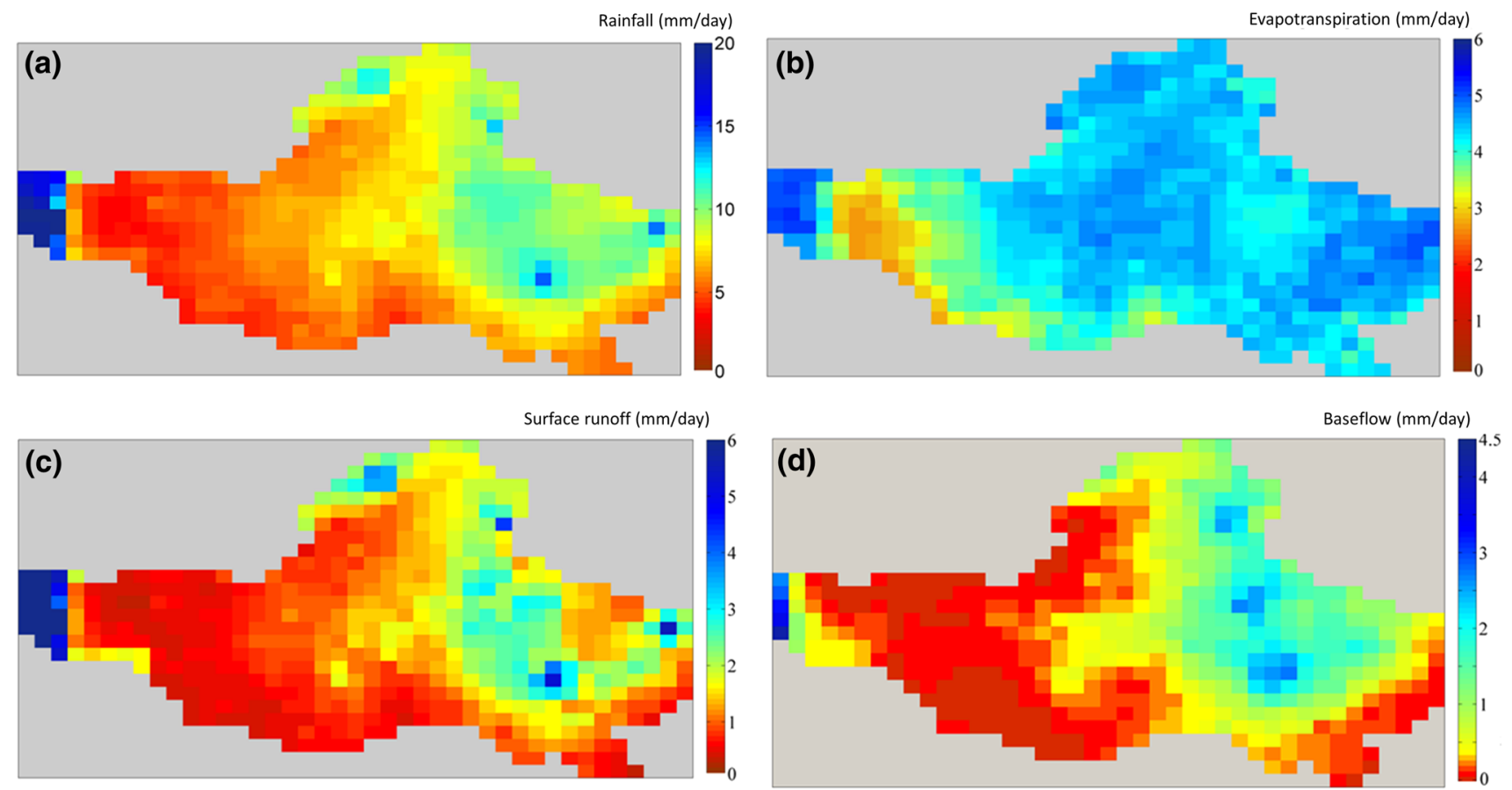

Figure 5. Spatial changes in hydrologic variables (mm/day) in the Godavari basin during the monsoon season (JJAS) (red colour shows low value and blue colour shows high value): (a) surface runoff; (b) baseflow and (c) evapotranspiration.

comparison. During 1981-1994, the dominant land uses in the study area were grassland/cropland $(70.22 \%)$ and woodland $(20.18 \%)$. In 2010 , the area of grassland/cropland $(60.65 \%)$ decreased by $9.57 \%$ and that of woodland $(29.37 \%)$ increased by
$9.19 \%$. The mixed forest cover increased by $5.48 \%$, while there were small changes in other forest covers. A negligible increase $(0.87 \%)$ was observed in the urban and built-up areas. The increase in mixed forest cover indicated that the forest 
Table 2. Comparison of land use in the Godavari basin for two different periods.

\begin{tabular}{|c|c|c|c|c|c|c|}
\hline \multirow[b]{2}{*}{ Land use } & \multicolumn{2}{|c|}{ Year (1984-1991) } & \multicolumn{2}{|c|}{ Year (2010) } & \multirow[b]{2}{*}{$\Delta_{\text {Area }}\left(\mathrm{km}^{2}\right)$} & \multirow[b]{2}{*}{$\Delta_{\text {Area }}(\%)$} \\
\hline & Area $\left(\mathrm{km}^{2}\right)$ & Area $(\%)$ & Area $\left(\mathrm{km}^{2}\right)$ & Area $(\%)$ & & \\
\hline Water & 3737.0 & 1.19 & 2448.3 & 0.78 & -1288.7 & -0.41 \\
\hline Evergreen broadleaf forest & 1202.6 & 0.38 & 420.8 & 0.13 & -781.8 & -0.25 \\
\hline Deciduous broadleaf forest & 426.9 & 0.14 & 6307.9 & 2.02 & 5881.1 & 1.88 \\
\hline Mixed forest & 0.0 & 0.00 & $17,131.2$ & 5.48 & $17,131.2$ & 5.48 \\
\hline Closed shrubland & $12,755.5$ & 4.08 & 477.8 & 0.15 & $-12,277.7$ & -3.93 \\
\hline Open shrubland & $11,566.8$ & 3.70 & 1160.5 & 0.37 & $-10,406.3$ & -3.33 \\
\hline Woodland & $63,127.4$ & 20.18 & $91,866.2$ & 29.37 & $28,738.9$ & 9.19 \\
\hline Grassland + cropland & $219,637.3$ & 70.22 & $189,710.2$ & 60.65 & $-29,927.1$ & -9.57 \\
\hline Urban and built & 205.9 & 0.07 & 2929.3 & 0.94 & 2723.5 & 0.87 \\
\hline Bare ground & 140.7 & 0.04 & 347.8 & 0.11 & 207.1 & 0.07 \\
\hline
\end{tabular}
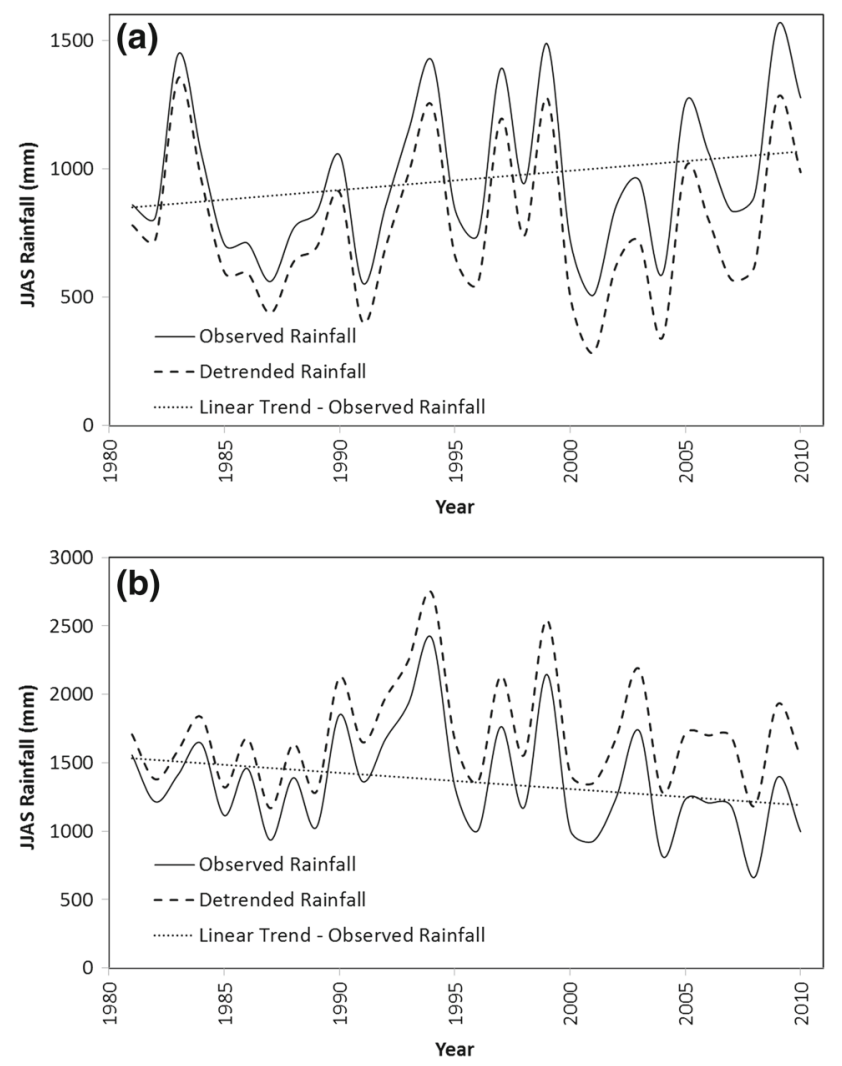

Figure 6. Grid-wise statistically significant rainfall trends in the GRB during the monsoon season (JJAS).

areas were becoming denser, whereas the shift from grassland/cropland to woodland indicates a decrease in agricultural activity in the GRB.

\subsection{Detrended climate variables}

According to the methodology described in section 3.3, a grid-wise seasonal trend analysis for the four seasons, namely DJF, MAM, JJAS, ON, was performed on the meteorological variables, i.e., rainfall, maximum temperature, minimum temperature and wind speed. The data series of de-trended meteorological variables was obtained by removing the significant trends (slope) in the observed data series from 1981 to 2010. Figure 6 represents the statistically significant (95\%) seasonal rainfall (JJAS) with increasing and decreasing trends at a single grid cell. Figure 7 represents the spatial distribution of the grids with statistically significant (95\%) increasing or decreasing seasonal rainfall trends (JJAS) in the GRB. The $p$-value varies from 0.0125 to 0.0477 for the grids with statistically significant trends. For the other gird locations with no significant trends in rainfall, $p$-values vary from 0.501 to 0.995 . Decreasing as well as increasing rainfall trends were observed at few grid locations for the monsoon period (JJAS). Decreasing trends were also observed during the summer season (MAM), which were not really significant for flow simulations. The decrease in rainfall was observed in the GRB because of climate change as summarised in table 3 , which was in agreement with the decreasing rainfall trend of the Indian monsoon (Saha et al. 2014). The average seasonal rainfall (JJAS) and average annual rainfall slightly decreased by $1.19 \%$ (from 923 to $912 \mathrm{~mm}$ ) and $0.93 \%$ (1113.72-1103.39 $\mathrm{mm})$, respectively. No statistically significant trend was observed for other forcing parameters such as minimum temperature, maximum temperature and wind speed. The detrended daily rainfall was used in the VIC hydrologic model to quantify the hydrological response of climate change, and the results are discussed in the following sections. 

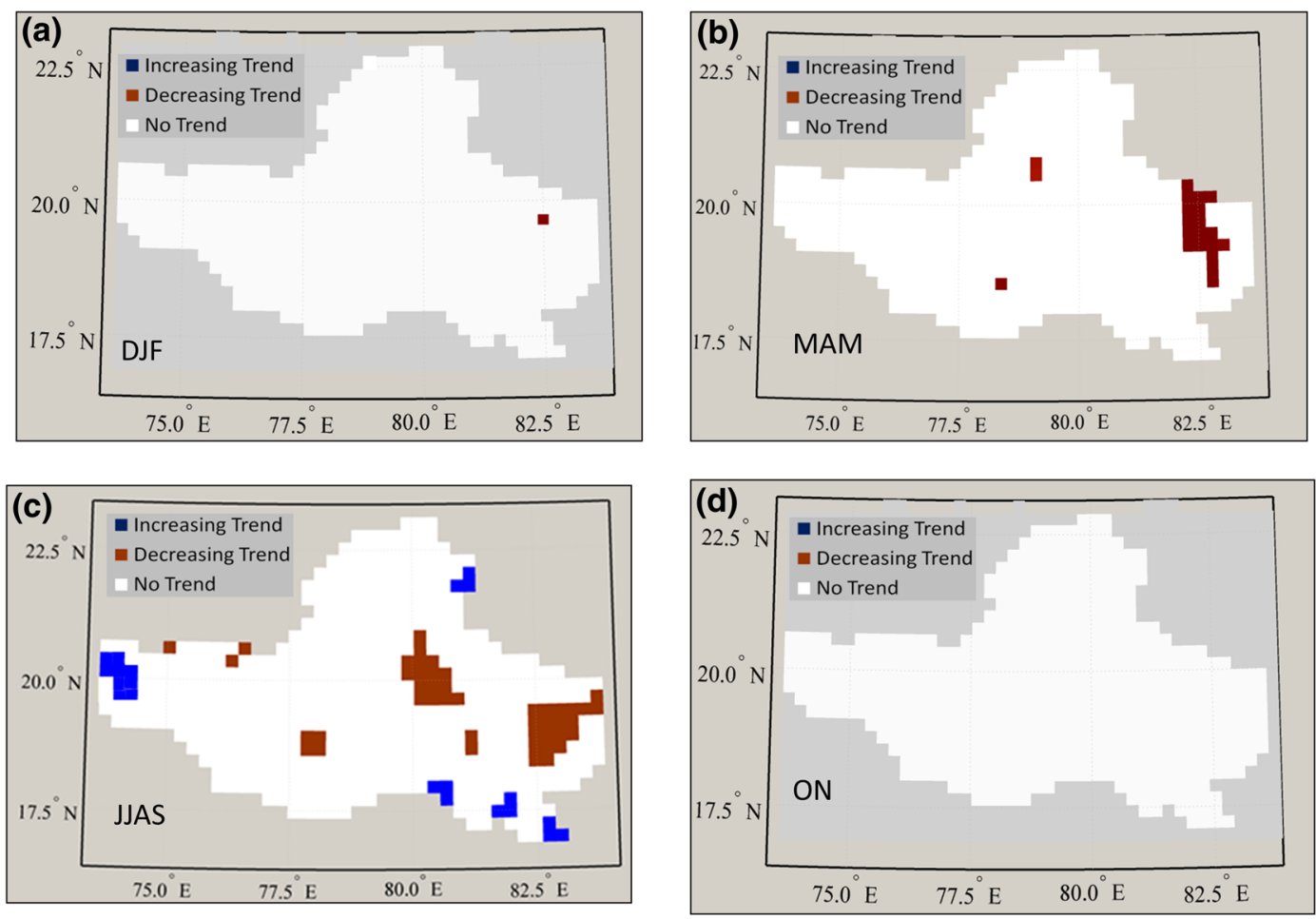

Figure 7. Statistically significant seasonal rainfall trends in the GRB: (a) DJF; (b) MAM; (c) JJAS and (d) ON.

\subsection{Impact of $L C$ and climate changes on hydrological variables}

The impact of LC changes and climate change on the hydrological variables for the GRB were quantified using three different scenarios. The scenarios were proposed to isolate the impact of the LC changes from climate change on river basin hydrology. Table 3 shows the average annual and seasonal de-trended rainfall i.e., rainfall for the baseline run and simulated water balance components for different scenarios and the baseline run in the GRB.

Figure $8(\mathrm{a}-\mathrm{c})$ represents the significant changes in average hydrological variables because of the LC changes for the monsoon period. It may be inferred that an increase in the forest cover (mixed forest and woodland) in the GRB caused the increase in evapotranspiration, and thus, the decrease in the surface runoff and baseflow. Evapotranspiration is usually higher for tree covered areas than for the areas without tree cover (Zhang et al. 2001). The average annual and seasonal evapotranspiration has been increased by $0.36 \%$ and $0.28 \%$, respectively. As a result of increased evapotranspiration, the average annual surface runoff and average annual baseflow have decreased. Table 3 indicates that the decreased average surface runoff for the monsoon period was negligible $(0.63 \%)$ and figure 8 (b) represents that the change in surface runoff was not significant at any grid location. Evapotranspiration generally depends on the soil moisture content and vegetation properties such as plant root depth and leaf area index. The root depth along with soil moisture controls the water drawing capacity of plants from the root zone. Trees with deep root zones can extract soil moisture from the lower soil layer when the top soil layer is dry or holding limited moisture content during the non-monsoon period. Deeper the root zone, greater the evapotranspiration for forest areas. It can be inferred that the variation in hydrological components may be due to the change in LC and/or human activities. Urbanisation also tends to increase the extent of impervious surfaces which cause a decrease in infiltration rate and an increase in the surface runoff although the area over which urbanisation changes have occurred was a small fraction of the GRB area.

Figure $8(\mathrm{~d}-\mathrm{f})$ represents the significant changes in the average hydrological variables because of the climate change in the monsoon period. Decreased average annual rainfall $(0.93 \%)$ and average seasonal rainfall $(1.19 \%)$ were observed because of climate change. The decreased rainfall resulted in a decrease in other water balance components as 


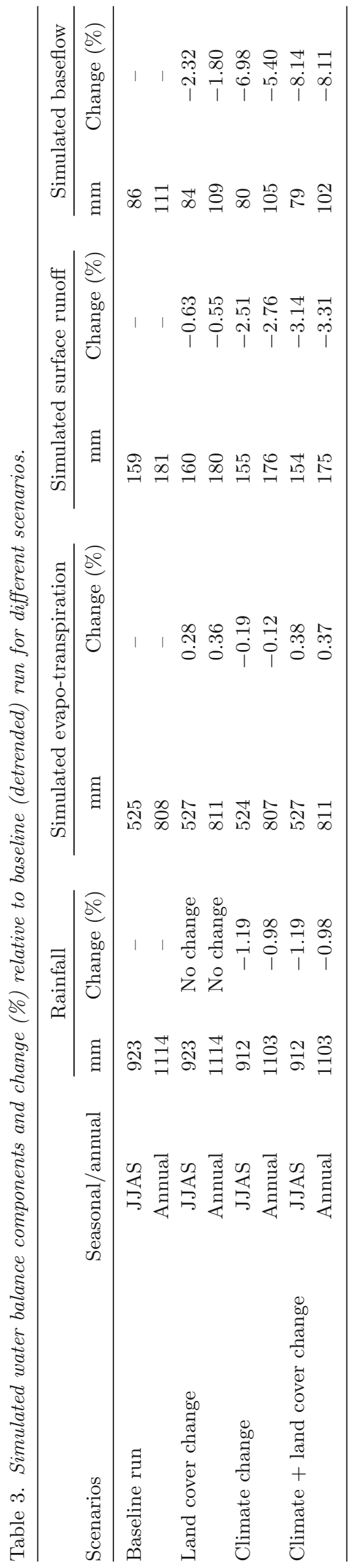

shown in table 3. A slight decrease was observed in the average seasonal (JJAS) evapotranspiration $(0.19 \%)$ because evapotranspiration is mainly determined by the vegetation class whenever the rainfall rate is higher than the maximum infiltration rate. Because there was no change in the LC for the climate change scenario, the changes in evapotranspiration were negligible. The soil was already saturated and achieved the maximum infiltration rate and potential evapotranspiration during the monsoon period for both the cases; without and with a decrease in rainfall. This phenomenon is generally true in the case of the Indian monsoon. The decrease in surface runoff and baseflow was dominant compared with that for evapotranspiration. A small decrease in the monsoon rainfall $(1.19 \%)$ resulted in a higher decrease in surface runoff $(2.51 \%)$ and baseflow $(6.98 \%)$. The excess rainfall after satisfying the maximum infiltration rate directly gets transformed into surface runoff/baseflow. Moreover, the GRB is in a high runoff potential region and underlines the dominance of Indian monsoon rainfall in governing the other water balance components.

Figure $8(\mathrm{~g}-\mathrm{i})$ represents the significant changes in average hydrological variables because of the climate and LC changes for the monsoon period. The decreased average seasonal rainfall and changed LC were accounted to simulate the combined impact of climate change and LC changes over the GRB. The percentage change in the hydrological variables is given in table 3 . The average seasonal (JJAS) evapotranspiration has increased by $0.38 \%$ though the rainfall has decreased. It may be inferred that the change in evapotranspiration is more sensitive to LC changes (increased mixed forest cover by $5.48 \%$ and woodland by $9.19 \%$ ) than the decreased average monsoon rainfall $(1.19 \%)$. The deeper root zones may be able to draw more water from the bottom soil layer causing higher evapotranspiration. A small decrease in the average monsoon rainfall $(1.19 \%)$ resulted in a higher decrease in the surface runoff $(3.14 \%)$ and baseflow (8.15\%). This shows that the surface runoff and baseflow are dominantly governed by the decreased rainfall. The decreased rainfall and increased forest cover, i.e., higher evapotranspiration, resulted in a considerable decrease in the surface runoff and baseflow, as given in table 3 . The hydrographs for the different scenarios are plotted (supplementary figure S4). The streamflow changes are smaller for the LC scenario compared with those for the climate change scenario. 

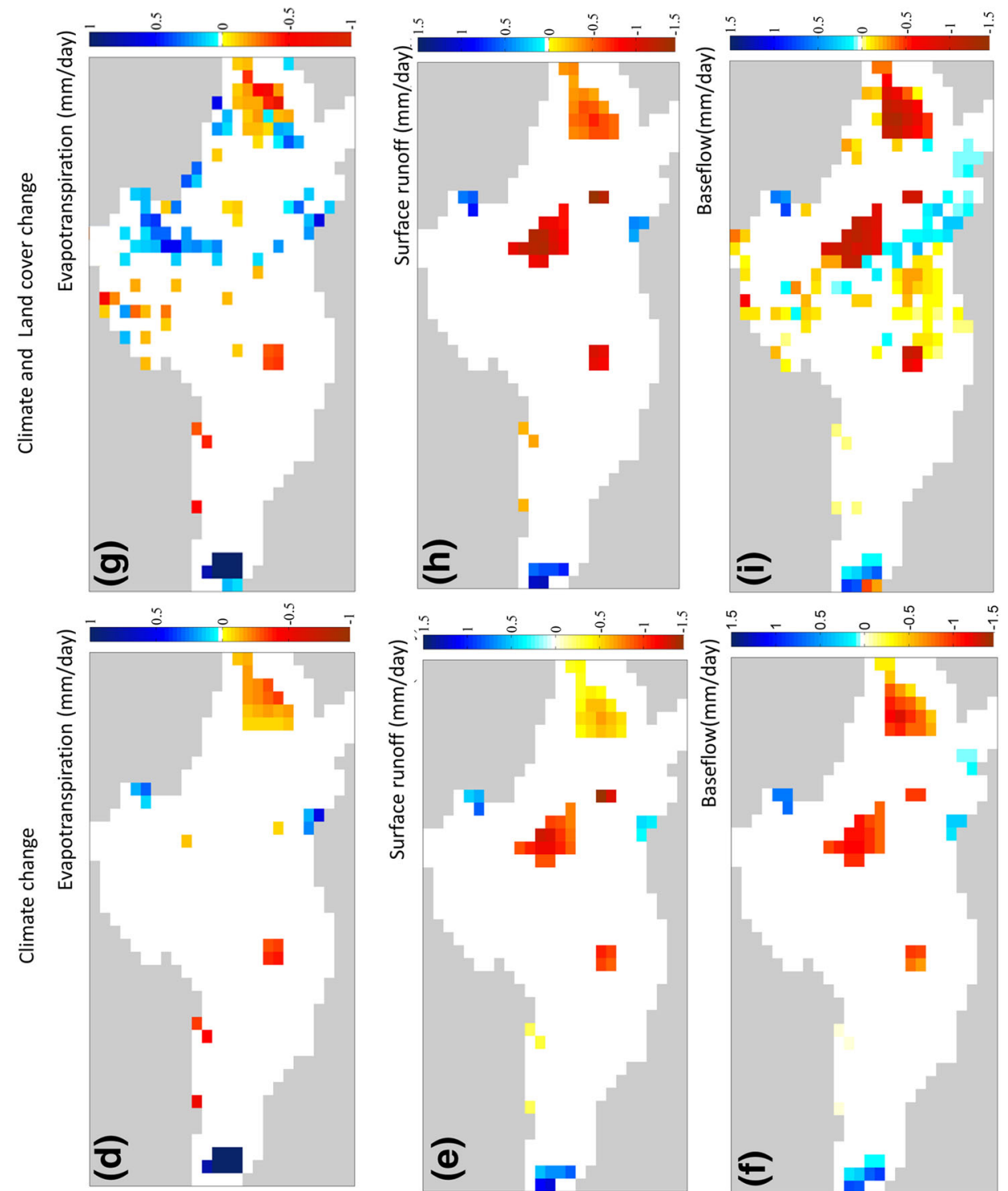

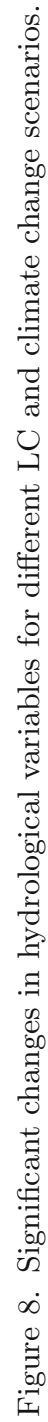
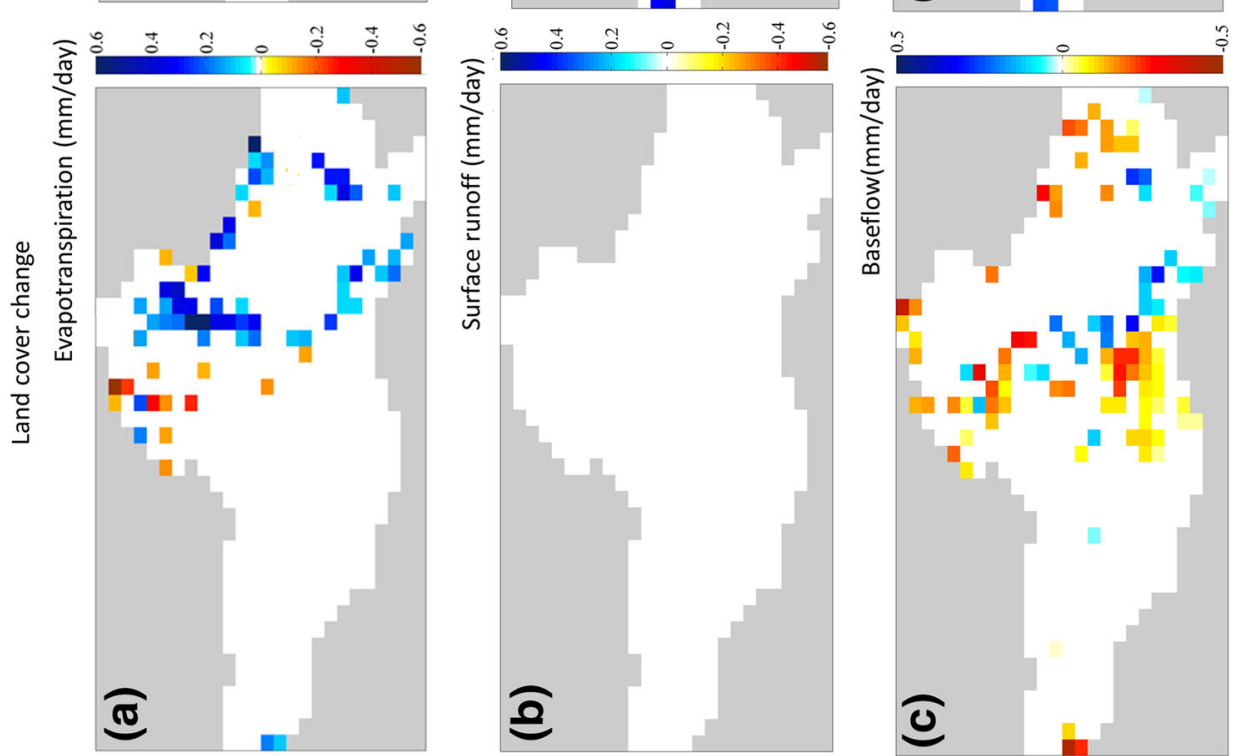
In conclusion, the LC changes were larger in areal extent compared with the changing rainfall trends that were observed at limited grids in the GRB. However, the study shows that the impact of the climate change on hydrologic fluxes is higher than that of LC changes in the GRB. It may be because of the saturated soil condition and maximum infiltration rate are achieved during the Indian monsoon season (JJAS). As the potential evapotranspiration is achieved during the monsoon period, its role in governing the runoff is restricted. In general, the excess rainfall after potential evapotranspiration directly contributes to runoff component. Therefore, the small change in rainfall due to climate change has a greater impact on hydrologic fluxes in the GRB than that of the LC changes.

\subsection{Model uncertainties}

The hydrological modelling has several uncertainties which influence the outcome of the model. The uncertainties in data are often caused by the lack of sufficient data availability and parameter estimation. Obtaining accurate model parameters for a large basin is a challenge as the parameters for the conceptual part need to be determined through direct observation. The VIC model uses already derived LC and soil parameters, which are constant within a land surface class and varies for different classes (Nijssen et al. 2000). Although this approach simplifies the application, it greatly reduces the number of governing parameters and introduces uncertainties in the model calibration. The meteorological gridded data (rainfall, temperature and wind) derived from the distribution of point data introduce errors because of regions with poor rainfall gauging network, spatio-temporal interpolation and bias correction.

The VIC model does not account for the impact of external factors such as irrigation and storage reservoirs that may result in an error in streamflows. In addition, the model does not consider dynamic trends in the vegetation that may affect the streamflows. The VIC model includes a maximum of three soil zones to model the vertical movement of soil moisture; however, it does not consider the groundwater. Despite several limitations and uncertainties, the results show that the VIC model is one of the suitable model for regional-scale surface hydrologic analysis.
In the present study, the annual volumetric error of $15 \%$ between the observed and simulated surface runoff by the VIC model is observed. These errors are inevitable during the calibration and validation of the model due to model or data uncertainty. However, once the model parameters are set, the changes in results are due to the variation in meteorological data i.e., rainfall and LC change only. As the statistically significant change in the input parameter i.e., rainfall is very minimal $(-1.19 \%)$, the subsequent changes in other hydrological variables such as surface runoff $(-3.14 \%)$ and baseflow $(-8.11 \%)$ are observed during the monsoon period. It indicates that the VIC model is simulating the hydrological processes but the GRB is a stable basin as far as the impact of rainfall trends (climate change) and LC changes are concerned.

\section{Conclusions}

In the present study, the relative impact of LC changes and climate change on the hydrological processes in the GRB were quantified using the VIC hydrologic model. The significant changes in the hydrological components were found by considering different scenarios such as LC change, climate change, and combined impact of climate and LC changes. Based on the study, the following conclusions are drawn:

- The VIC hydrologic model includes a large number of physical parameters which govern the hydrological processes. The suitability of the VIC hydrological model to quantify the relative impact of LC changes and climate change is strengthened by its structure to account for the global or regional databases.

- The routing model associated with the VIC model simulates the naturalised flow without considering the reservoir storage. In the present study, the impact of the storage structure was negligible as the observed stream discharges at the Tekra runoff gauging station were selected to calibrate and validate the model. Furthermore, the results may be improved if a reservoir model is coupled with the routing model.

- The LC changes for two different periods indicate that the forest areas are becoming denser and shift of grassland/cropland to woodland indicates the decreased agricultural activity in the GRB. A small or insignificant increase in built-up and urban (0.87\%) was also observed. 
The increased tree cover causes more evapotranspiration and decrease in water yield.

- A grid-wise seasonal trend analysis shows an overall decrease in monsoon rainfall (JJAS) in the GRB because of significant decreasing rainfall trends at few grid cells. The decreased rainfall resulted in a slight decrease in evapotranspiration and a higher decrease in runoff.

- LC changes were observed on higher areal extent compared with the changing rainfall trends that were observed at limited grid locations in the GRB. The study shows that the changing climate has a greater impact on the basin hydrology compared with the LC changes.

\section{Acknowledgements}

The authors sincerely acknowledge the Central Water Commission (CWC) for providing streamflow data at various locations in the Godavari river basin. The first author is thankful to Prof. Subimal Ghosh for his suggestions, help and valuable guidance.

\section{References}

Aggarwal S P, Garg V, Gupta P K, Nikam B R, Thakur P K and Roy P S 2013 Run-off potential assessment over Indian landmass: A macro-scale hydrological modelling approach; Curr. Sci. 104(7) 950-959.

Babar S and Ramesh H 2015 Streamflow response to land use-land cover change over the Nethravathi river basin, India; J. Hydrol. Eng., https://doi.org/10.1061/ (ASCE)HE.1943-5584.0001177.

Bewket W and Sterk G 2005 Dynamics in land cover and its effect on stream flow in the Chemoga watershed, Blue Nile basin, Ethiopia; Hydrol. Process. 19(2) 445-458.

Burns D H 2008 Climatic influences on streamflow timing in the headwaters of the Mackenzie river basin; $J$. Hydrol. 352(1-2) 225-238.

Cao C, Xiong X, Wu A and Wu X 2008 Assessing the consistency of AVHRR and MODIS L1B reflectance for generating fundamental climate data records; J. Geophys. Res. Atmos. 113(D9) 1-10.

Cuo L, Zhang Y, Gao Y, Hao Z and Cairang L 2013 The impacts of climate change and land cover/use transition on the hydrology in the upper Yellow River basin, China; J. Hydrol. 502 37-52.

Dong L, Xiong L, Lall U and Wang J 2015 The effects of land use change and precipitation change on direct runoff in Wei river watershed, China; Water Sci. Technol. 71(2) 289-295.

Dooge J, Bruen M and Parmentier B 1999 A simple model for estimating the sensitivity of runoff to long-term changes in precipitation without a change in vegetation; Adv. Water Resour. 23(2) 153-163.
Dunn S M 1998 Large scale modelling using small scale processes in hydrology in a changing environment; In: (eds) Wheater H and Kirby C, Wiley, Chichester, pp. 1120.

FAO 2003 The digitized soil map of the world and derived soil properties (version 3.5); FAO Land and Water Digital Media Series 1, FAO, Rome.

Foley J A, De Fries R, Asner G P, Barfor C, Bonan G, Carpenter S R, Chapin F S, Coe M T, Daily G C, Gibbs H K, Helkowski J H, Holloway T, Howard E A, Kucharik C J, Monfreda C, Patz J A, Prentice I C, Ramankutty N and Snyder P K 2005 Global consequences of land use; Science 309 570-574.

Guo Q, Yunsong Yang Y and Xiong X 2016 Using hydrologic simulation to identify contributions of climate change and human activity to runoff changes in the Kuye river basin, China; Environ. Earth Sci. 75(417) 1-10, https://doi. org/10.1007/s12665-016-5280-7.

Hamlet A F and Lettenmaier D P 1999 Effects of climate change on hydrology and water resources in the Columbia river basin; J. Am. Water Resour. Assoc. 35(6) 15971623.

Hansen M C, Defries R S, Townshend J R G and Sohlberg R 2000 Global land cover classification at $1 \mathrm{~km}$ spatial resolution using a classify cation tree approach; Int. J. Remote Sens. 21(6-7) 1331-1364.

Hengade N and Eldho T I 2016 Assessment of LULC and climate change on the hydrology of Ashti catchment, India using VIC model; J. Earth Syst. Sci. 125(8) 16231634 .

Huo A and Li H 2013 Assessment of climate change impact on the stream-flow in a typical debris flow watershed of Jianzhuangcuan catchment in Shaanxi province, China; Environ. Earth Sci. 9(6) 1931-1938.

Jiang Y, Liu C and Li X 2015 Hydrological impacts of climate change simulated by HIMS models in the Luanhe river basin, North China; Water Resour. Manag. 29 13651384 .

Kalnay E, Kanamitsu M and Kistler R 1996 The NCEP/NCAR 40-years reanalysis project; Bull. Am. Meteorol. Soc. 77(3) 437-471.

Koster R D and Suarez M J 1999 A simple framework for examining the interannual variability of land surface moisture fluxes; J. Clim. 12(7) 1911-1917.

Kristensen K J and Jensen S E 1975 A model for estimating actual evapotranspiration from potential evapotranspiration; Hydrol. Res. 6(3) 170-188.

Liang X, Lettenmaier D P, Wood E F and Burges S J 1994 A simple hydrologically based model of land surface water and energy fluxes for general circulation models; J. Geophys. Res. 99 14415-14428.

Liang X, Lettenmaier D P and Wood E F 1996 Onedimensional statistical dynamic representation of subgrid variability of precipitation in the two-layer variable infiltration capacity model; J. Geophys. Res. 101403 421.

Liu Y, Zhang X, Xia D, You J, Rong Y and Bakir M 2013 Impacts of land-use and climate changes on hydrologic processes in the Qingyi river watershed, China; J. Hydrol. Eng. 18(11) 1495-1512.

Lohmann D, Nolte-Holube R and Raschke E 1996 A large-scale horizontal routing model to be coupled to 
land surface parameterization schemes; Tellus 48A 708721.

Maurer E P, Wood A W, Adam J C, Lettenmaier D P and Nijssen B 2002 A long-term hydrologically-based data set of land surface fluxes and states for the conterminous United States; J. Clim. 15 3237-3251.

Morán-Tejeda E, Ceballos-Barbancho A and Llorente-Pinto J M 2010 Hydrological response of Mediterranean headwaters to climate oscillations and land-cover changes: The mountains of Duero river basin (Central Spain); Glob. Planet Change 72(1-2) 39-49.

National Remote Sensing Centre and Central Water Commission 2011 Assessment of water resources at basin scale using space input-A pilot study-Godavari and Brahmani-Baitarani Basins.

Nijssen B, Greg O'Donnell M and Lettenmair D P 2000 Predicting the discharge of global rivers; J. Clim. 14(15) 3307-3323.

Nijssen B, Greg O'Donnell M, Hamlet A F and Lettenmaier D P 2001 Hydrologic sensitivity of global rivers to climate change; Clim. Change 50 143-175.

Raje D and Krishnan R 2012 Bayesian parameter uncertainty modeling in a macroscale hydrologic model and its impact on Indian river basin hydrology under climate change; Water Resour. Res. 48 1-17.

Rajeevan M, Bhate J, Kale J D and Lal B 2005 Development of a high resolution daily gridded rainfall data for the Indian region: Analysis of break and active monsoon spells; Technical Report, India Meteorological Department.

Saghafian B, Farazjoo H, Bozorgy B and Yazdandoost F 2008 Flood intensification due to changes in land use; Water Resour. Manage. 22 1051-1067.

Saha A S, Ghosh S, Sahana A S and Rao E P 2014 Failure of CMIP5 climate models in simulating post-1950 decreasing trend of Indian monsoon; Geophys. Res. Lett. 417323 7330 .

Savary S, Rousseau A N and Quilbe R 2009 Assessing the effects of historical land cover changes on runoff and low flows using remote sensing and hydrological modeling; J. Hydrol. Eng., https://doi.org/10.1061/(ASCE)HE. 1943-5584.0000024.

Shah H L and Mishra V 2016 Hydrologic changes in Indian subcontinental river basins (1901-2012); J. Hydrometeor. 17 2667-2687.

Todini E 1996 The ARNO rainfall-runoff model; $J$. Hydrol. 175 339-382.

Yan R, Gao J and Lingling L 2016 Streamflow response to future climate and land use changes in Xinjiang basin, China; Environ. Earth Sci. 75 1108. 1-15.

Zhang L, Dawes W R and Walker G R 2001 Response of mean annual evapotranspiration to vegetation changes at catchment scale; Water Resour. Res. 37(3) 701708 . 